\title{
Petroleum systems and structures offshore central West Greenland: implications for hydrocarbon prospectivity
}

\author{
Ulrik Gregersen, Torben Bidstrup, Jørgen A. Bojesen-Koefoed, Flemming G. Christiansen, \\ Finn Dalhoff and Martin Sønderholm
}

A detailed geophysical mapping project has been carried out by the Geological Survey of Denmark and Greenland (GEUS) in the offshore region south-west and west of Disko and Nuussuaq, central West Greenland as part of the preparations for the Disko West Licensing Round in 2006 (Fig. 1). The main purpose of the study was to evaluate the prospectivity of this almost $100000 \mathrm{~km}^{2}$ large region, and to increase knowledge of basin evolution and the structural development. Results of the work, including a new structural elements map of the region and highlights of particular interest for hydrocarbon exploration of this area, are summarised below.

Evidence of live petroleum systems has been recognised in the onshore areas since the beginning of the 1990s when seeps of five different oil types were demonstrated (BojesenKoefoed et al. 1999). Oil seeps suggesting widely distributed marine source rocks of Mesozoic age are particularly promising for the exploration potential (Bojesen-Koefoed et al. 2004, 2007). Furthermore, possible DHIs (Direct Hydrocarbon Indicators) such as gas-clouds, pock marks, bright spots and flat events have been interpreted in the offshore region (Skaarup et al. 2000; Gregersen \& Bidstrup in press).

The evaluation of the region (Fig. 1) is based on all public and proprietary seismic data together with public domain magnetic and gravity data. The seismic data (a total of c. 28000 line $\mathrm{km}$ ) are tied to the two existing offshore exploration wells in the region (Hellefisk-1 and Ikermiut-1). The study also incorporates information on sediments and volcanic rocks from onshore Disko and Nuussuaq (Fig. 2).

Ten seismic horizons ranging from 'mid-Cretaceous' to 'Base Quaternary' (Fig. 2) have been interpreted regionally. Large correlation distances to wells, varying data quality and a thick cover of basalt in the north-eastern part of the region, add uncertainty in the regional interpretation, especially for the deeper horizons such as the 'mid-Cretaceous' equivalent to Santonian sandstone interval drilled in Qulleq-1 far south.

Based on the seismic interpretation (Fig. 3) structural elements maps, horizon-depth maps and isopach maps have been produced; these maps, together with general stratigraphic knowledge on potential reservoirs, seals and source rocks (Fig. 2), provide important information for discussions of critical play elements including kitchens and structures.
The existence of many large structures combined with the evidence of live petroleum systems has spurred the recent major interest for hydrocarbon exploration in the region.

\section{Structural development and basin evolution}

A number of deep basins with Cretaceous and Cenozoic sedimentary successions have been recognised offshore West Greenland since the 1970s (e.g. Chalmers et al. 2001). In Early to mid-Cretaceous times a number of major structural complexes and basins developed in the region (Figs 1, 3), mainly as a result of extensional faulting. These include the

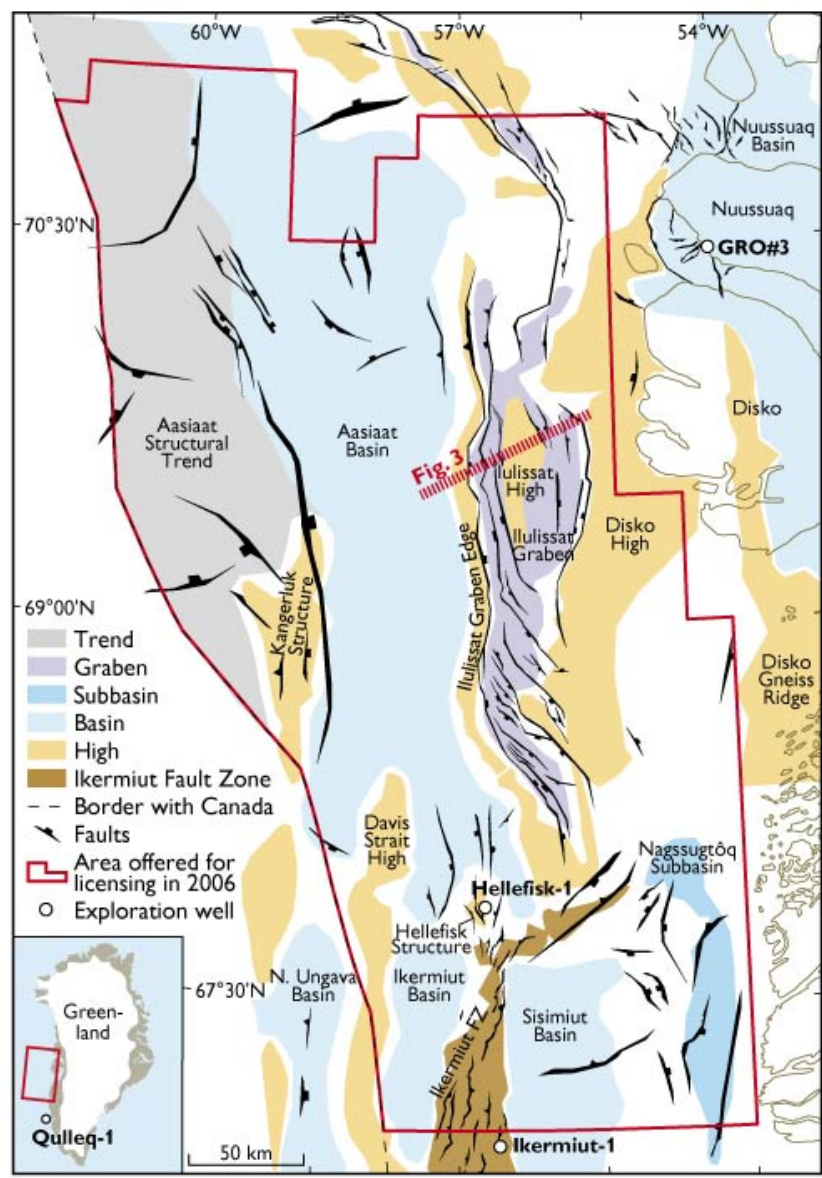

Fig. 1. Structural elements offshore the Disko-Nuussuaq region, central West Greenland. The position of the seismic example in Fig. 3 is shown. 


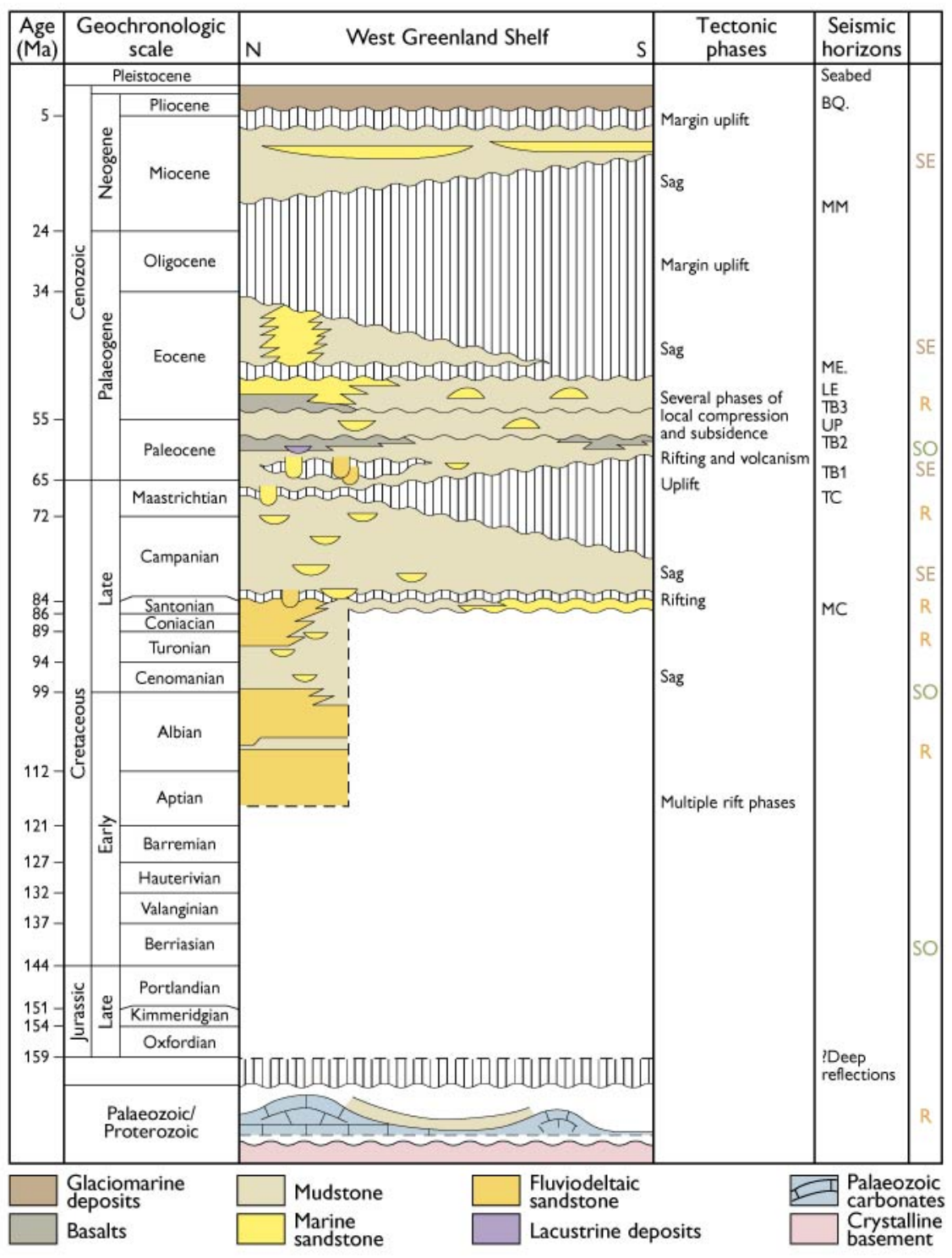

Fig. 2. Simplified stratigraphic scheme with lithology from present coastal areas of Disko and Nuussuaq (north), and from offshore

West Greenland wells towards the south. The main phases of tectonism and subsidence are listed. The main interpreted seismic horizons are Seabed, Base Quaternary (BQ), midMiocene (MM), Lower Eocene (LE), Top Basalt 3 (TB3), Upper Paleocene (UP), Top Basalt 2 (TB2), Top Basalt 1/Base Basalt 2 (TB1), Top Cretaceous (TC), mid-Cretaceous (MC) and unspecified deep reflections.

The most likely intervals with source rocks (SO), reservoir sands (R) and seals (SE) are also indicated.

Aasiaat Structural Trend, the Kangerluk Structure, the Aasiaat Basin, the Sisimiut Basin and the Nagssugtôq Subbasin (Fig. 1). Deep-seated fault-bounded basins locally showing anticlinal structures are occasionally observed below the interpreted 'mid-Cretaceous' seismic horizon. Seabed sampling has shown the presence of Ordovician carbonate strata on the Davis Strait High (Dalhoff et al. 2006). Together with reworked Jurassic or older palynomorphs observed in the Qulleq-1 well farther south (NøhrHansen et al. 2000) these suggest the possibility of pre-Cretaceous strata in the deepest parts of these basins. Based on outcrop studies, regional Cretaceous sand-prone units are expected to be present in the offshore region, both as deltaic and shallow-marine deposits and as turbidite deposits (Fig. 2).

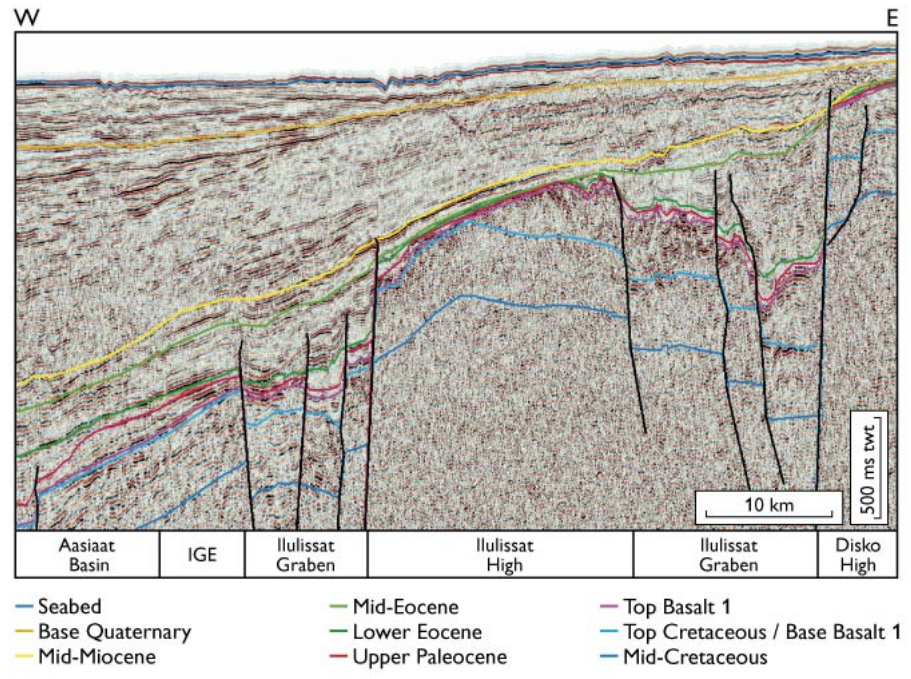

During the Late Cretaceous a new rifting episode was initiated and was characterised by normal faulting, subsidence and syn-rift sedimentation including deposition of a thick mudstone succession of Campanian-Maastrichtian age (Dam et al. 2000). This phase lasted into Early Paleocene times resulting in repeated erosion and filling of subaerial valley and submarine canyons and formation

Fig. 3. Seismic section (GGUi95-17) through eastern parts of the study region, showing main structural elements. The main structural elements are from west to east: The easternmost parts of the Aasiaat Basin, the Ilulissat Graben Edge (IGE), the Ilulissat Graben on both sides of the Ilulissat High, and the westernmost part of the Disko High. Note the amplitude anomalies above the Ilulissat High (see Fig. 1 for location). 
Fig. 4. Simplified prospectivity map. Cretaceous to Palaeogene structures and major midCretaceous 4-way dip closures to the west, possible hydrocarbon migration pathways and mid-Cretaceous hydrocarbon generation areas (maturity levels - early to main oil: $\sim 0.5->1 \%$ $\mathrm{R}_{\mathrm{o}}$; late oil: $\sim 1->1.3 \% \mathrm{R}_{\mathrm{o}}$; gas: $>1.3 \% \mathrm{R}_{\mathrm{o}}$ ).

of regional unconformities (Dam \& Sønderholm 1998; Dam 2002).

A zircon age provenance study of sandstone units in outcrops and offshore exploration wells indicates that most of the sand units show local age signatures characteristic of the Greenland shield to the east. However, a Grenville age component of probable Canadian derivation also seems to be present in the deep-water deposits of the Nuussuaq Basin and in the Qulleq-1 well suggesting a long-shore transport component (Scherstén \& Sønderholm 2007 - this volume).

During the Paleocene-Eocene a major episode of volcanic eruption took place, and some hundreds of metres of thick basalts cover part of the offshore region (Fig. 3). The basalts may reach thicknesses of more than $2 \mathrm{~km}$ in the north-eastern offshore part of the study region. However, the current mapping suggests that the volcanic succession is thinner and less widely distributed than suggested in previous publications and maps (e.g. Chalmers et al. 1993; Chalmers \& Pulvertaft 2001; Skaarup 2002). Strike-slip movements during the Late Paleocene and Early Eocene caused local transpression of structures primarily along the Ikermiut Fault Zone, and locally in the basins and structures farther north, contemporaneous with subsidence in the Ikermiut Basin region. Transtensional and extensional movements farther to the north-east, subsequent to the extrusion of the Paleocene basalts, resulted in the development of the more than $200 \mathrm{~km}$ long Ilulissat Graben (Fig. 1).

During the Eocene, and especially during the late Miocene to Pliocene, the offshore basins subsided rapidly, and large sedimentary wedges prograded towards the west and south, possibly as a consequence of Neogene uplift in the present onshore areas to the east (Fig. 3; Dalhoff et al. 2003; Japsen et al. 2005; Bonow et al. 2007 - this volume).

\section{Petroleum systems and prospectivity}

Based on seismic interpretation, depth conversion using seismic velocities, sonic log data from the wells and the thermal maturity gradient from selected wells, the most likely source rock intervals (mid-Cretaceous and Lower Paleocene) seem to be mature in large parts of the region (Fig. 4), though seismic interpretation is difficult.

In particular the Aasiaat Basin, the Aasiaat Structural Trend, the North Ungava Basin, the Ikermiut Basin, the Sisimiut Basin and the Ilulissat Graben (Fig. 1) may have adequate dimensions and depths to have potential as kitchens for hydrocarbon generation, with the potential also depending on factors such as source rocks being present in sufficient quality and quantity. This study indicates that the interpreted 
source rock intervals possibly came into the oil window after mid-Miocene time, subsequent to the formation of the main structural closures providing a favourable timing for charging.

In the interpreted Cretaceous and Cenozoic sections, amplitude anomalies are locally observed and may be interpreted as DHIs (such as e.g. bright spots above the Ilulissat High in Fig. 3) that could be caused by trapped hydrocarbon. Clusters of DHIs are located especially over or near the supposed Cretaceous kitchen areas, and also locally where satellite slicks have been recorded (Fig. 4), and contribute to an indication of live petroleum systems in the offshore region.

Mapping of the Cretaceous and Palaeogene intervals and structural highs has revealed many structures. Large structural closures can be outlined both in the western part of the region (in the Aasiaat Basin, the Aasiaat Structural Trend and the Kangerluk Structure), in the eastern part of the region (both along the edge and within the Ilulissat Graben) and in the southern part of the region related to the Ikermiut Fault Zone (Fig. 4). The Cretaceous and Palaeogene structural closures are situated close to supposed kitchen areas (Fig. 4), and together with the oil seeps and reservoir quality sandstones known onshore and their supposed offshore equivalents, these elements indicate that the offshore area west and south of Disko could potentially be prospective.

\section{Acknowledgements}

The geophysical study was supported by the Bureau of Minerals and Petroleum, Government of Greenland. TGS-NOPEC and NUNAOIL A/S are thanked for permission to publish the structural maps that incorporate proprietary seismic and satellite slick data.

\section{References}

Bojesen-Koefoed, J.A., Christiansen, F.G., Nytoft, H.P. \& Pedersen, A.K. 1999: Oil seepage onshore West Greenland: evidence of multiple source rocks and oil mixing. In: Fleet, A.J. \& Boldy, S.A.R. (eds): Petroleum geology of Northwest Europe: proceedings of the 5 th conference, 305-314. London: Geological Society.

Bojesen-Koefoed, J.A., Nytoft, H.P. \& Christiansen, F.G. 2004: Age of oils in West Greenland: Was there a Mesozoic seaway between Greenland and Canada? Geological Survey of Denmark and Greenland Bulletin 4, 49-52.

Bojesen-Koefoed, J.A., Bidstrup, T., Christiansen, F.G., Dalhoff, F., Gregersen, U., Nytoft, H.P., Nøhr-Hansen, H., Pedersen, A.K. \& Sønderholm, M. 2007: Petroleum seepages at Asuk, Disko, West Greenland - implications for regional petroleum exploration. Journal of Petroleum Geology 30, 219-236.

Bonow, J.M., Japsen, P., Green, P.F., Wilson, R.F., Chalmers, J.A., Klint, K.E., van Gool, J.A.M., Lidmar-Bergström, K. \& Pedersen, A.K. 2007 : A multi-disciplinary study of Phanerozoic landscape development in
West Greenland. Geological Survey of Denmark and Greenland Bulletin 13, 41-44.

Chalmers, J.A. \& Pulvertaft, T.C.R. 2001: Development of the continental margins of the Labrador Sea - a review. In: Wilson, R.C.L. et al. (eds): Non-volcanic rifting of continental margins: a comparison of evidence from land and sea. Geological Society Special Publication (London) 187, 79-107.

Chalmers, J.A., Pulvertaft, T.C.R., Christiansen, F.G., Larsen, H.C., Laursen, K.H. \& Ottesen, T.G. 1993: The southern West Greenland continental margin: rifting history, basin development, and petroleum potential. In: Parker, J.R. (ed.): Petroleum geology of NW Europe: proceedings of the 4th conference, 915-931. London: Geological Society.

Chalmers, J.A., Christiansen, F.G., Sønderholm, M., Olsen, J.C., Myklebust, R. \& Schønwandt, H.K. 2001: Geological information base growing on North Atlantic rift basins. Data developed for Greenland licensing. Offshore 61(11), 87-89, 100.

Dalhoff, F., Chalmers, J.A., Gregersen, U., Nøhr-Hansen, H., Rasmussen, J.A. \& Sheldon, E. 2003: Mapping and facies analysis of Paleocene-Mid-Eocene seismic sequences, offshore southern West Greenland. Marine and Petroleum Geology 20, 935-986.

Dalhoff, F., Larsen, L.M., Ineson, J.R., Stouge, S., Bojesen-Koefoed, J.A., Lassen, S., Kuijpers, A., Rasmussen, J.A. \& Nøhr-Hansen, H. 2006: Continental crust in the Davis Strait: new evidence from seabed sampling. Geological Survey of Denmark and Greenland Bulletin 10, 33-36.

Dam, G. 2002: Sedimentology of magmatically and structurally controlled outburst valleys along rifted volcanic margins; examples from the Nuussuaq Basin, West Greenland. Sedimentology 49, 505-532.

Dam, G. \& Sønderholm, M. 1998: Sedimentological evolution of a faultcontrolled Early Paleocene incised-valley system, Nuussuaq Basin, West Greenland. In: Shanley, K.W. \& McCabe, P.J. (eds): Relative role of eustasy, climate, and tectonism in continental rocks. Society for Sedimentary Geology (SEPM) Special Publication 59, 109-121.

Dam, G., Nøhr-Hansen, H., Pedersen, G.K. \& Sønderholm, M. 2000: Sedimentary and structural evidence of a new early Campanian rift phase in the Nuussuaq Basin, West Greenland. Cretaceous Research 21, $127-154$

Gregersen, U. \& Bidstrup, T. in press: Structures and hydrocarbon prospectivity in the northern Davis Strait area, offshore West Greenland. Petroleum Geoscience.

Japsen, P., Green, P.F. \& Chalmers, J.A. 2005: Separation of Palaeogene and Neogene uplift on Nuussuaq, West Greenland. Journal of the Geological Society (London) 162, 299-314.

Nøhr-Hansen, H., Piasecki, S., Rasmussen, J.A. \& Sheldon, E. 2000: Biostratigraphy of well 6354/4-1 (Qulleq-1), West Greenland. Danmarks og Grønlands Geologiske Undersøgelse Rapport 2000/101, 81 pp.

Scherstén, A. \& Sønderholm, M. 2007: Provenance of Cretaceous and Paleocene sandstones in the West Greenland basins based on detrital zircon dating. Geological Survey of Denmark and Greenland Bulletin 13, 37-41.

Skaarup, N. 2002: Evidence for continental crust in the offshore Palaeogene volcanic province, central West Greenland. Geology of Greenland Survey Bulletin 191, 97-102.

Skaarup, N., Chalmers, J.A. \& White, D. 2000: An AVO study of a possible new hydrocarbon play, offshore central West Greenland. American Association of Petroleum Geologists Bulletin 84, 174-182.

\section{Authors' address}

Geological Survey of Denmark and Greenland, Øster Voldgade 10, DK-1350 Copenhagen K, Denmark. E-mail: ug@geus.dk 